\title{
Neuroblastoma Suppressor of Tumorigenicity 1
}

National Cancer Institute

\section{Source}

National Cancer Institute. Neuroblastoma Suppressor of Tumorigenicity 1. NCI

Thesaurus. Code C17791.

Neuroblastoma suppressor of tumorigenicity 1 (180 aa, $19 \mathrm{kDa}$ ) is encoded by the human NBL1 gene. This protein may play a role in signal transduction. 